\title{
Taxonomy of Podoscirtinae (Orthoptera: Gryllidae). Part 14: the genera Ocellotrella gen.n. and Neozvenella from Madagascar
}

\author{
Таксономия подсемейства Podoscirtinae (Orthoptera: Gryllidae). \\ Часть 14: роды Ocellotrella gen.n. и Neozvenella из Мадагаскара
}

\begin{abstract}
A.V. Gorochov
A.B. Горохов

Zoological Institute, Russian Academy of Sciences, Universitetskaya Emb. 1, St Petersburg 199034, Russia. E-mail: orthopt@zin.ru Зоологический институт РАН, Университетская наб. 1, Санкт- Петербург 199034, Россия.

KEYWORDS: Orthoptera, Gryllidae, Podoscirtinae, Podoscirtini, crickets, Madagascar, taxonomy, new taxa.

КЛЮЧЕВЫЕ СЛОВА: Orthoptera, Gryllidae, Podoscirtinae, Podoscirtini, сверчки, Мадагаскар, таксономия, новые таксоны.
\end{abstract}

ABSTRACT. Some Madagascan taxa belonging to the subtribe Podoscirtina of the tribe Podoscirtini are considered. A new genus with a new species and three new species of the genus Neozvenella Gor. are described from Madagascar: Ocellotrella sharovae gen. et sp.n., $N$. brunnea sp.n., N. adunca sp.n. and N. paraucta sp.n. Additional data on three other species of Neozvenella are also provided, including descriptions of previously unknown females of $N$. picta Gor. and N. aucta Gor.

РЕЗЮМЕ. Рассмотрены некоторые мадагаскарские таксоны, принадлежащие подтрибе Podoscirtina трибы Podoscirtini. C Мадагаскара описаны новый род с одним новым видом и три новых вида рода Neozvenella Gor.: Ocellotrella sharovae gen. et sp.n., $N$. brunnea sp.n., $N$. adunca sp.n. и $N$. paraucta sp.n. Приведены также дополнительные данные по трём другим видам Neozvenella, в том числе описания ранее неизвестных самок N. picta Gor. и N. aucta Gor.

\section{Introduction}

This paper is the fourteenth communication in the series of publications on taxonomy of the cricket subfamily Podoscirtinae. It continues the third and fifth communications which were dedicated mainly to Madagascan representatives of the tribe Podoscirtini [Gorochov, 2004, 2006]. In these papers, the Madagascan genera together with some African ones were placed in "Podoscirtus" generic group. Later for this group, the subtribe Podoscirtina was established [Gorochov, 2021]; but one genus from Madagascar (Fryerius Uvarov, 1940) was not included in this subtribe, as its relationships with the other genera of this subtribe was problematic. Now the belong- ing of this genus to Podoscirtina seems more probable, because the new genus described here has the male genitalia somewhat intermediate between those of Fryerius and the other Madagascan genera.

\section{Material and methods}

The material used in this paper is deposited at the following institutions: Zoological Institute, Russian Academy of Sciences, St Petersburg (ZIN); Natural History Museum, London (NHM). All the specimens are dry and pinned. Photographs of their morphological structures were made using a Leica M216 stereomicroscope and DFC290 camera.

\section{Taxonomic part}

Tribe Podoscirtini Saussure, 1878 Subtribe Podoscirtina Saussure, 1878

Genus Ocellotrella Gorochov, gen.n.

Type species Ocellotrella sharovae Gorochov, sp.n.

DIAGNOSIS. Body rather small and moderately thin for this subtribe. Head somewhat dorsoventrally flattened, with roundly angular rostrum in profile; scape almost twice as wide as rostrum between antennal cavities; lateral ocelli very large, contacting with each other along median line; median ocellus much smaller, oval, slightly obliterated, located before lateral ocelli on rostral dorsum (Figs 1-2); maxillary palpus not very long (its fifth segment almost as long as height of eye), with distinctly but not strongly widened apical part. Pronotum barely longer than wide, insignificantly narrowing to head, with anterior and posterior edges of disc almost straight (Fig. 2); lateral pronotal lobes moderately low

How to cite this article: Gorochov A.V. 2021. Taxonomy of Podoscirtinae (Orthoptera: Gryllidae). Part 14: the genera Ocellotrella gen. n. and Neozvenella from Madagascar // Russian Entomol. J. Vol.30. No.4. P.381-389. doi: 10.15298/rusentj.30.4.01 
and with more or less rounded ventral edges (Fig. 5). Metanotal gland developed only in male, not pubescent, with almost lamellar transverse fold in anterior part of metanotum, and with distinct median convexity narrower behind (near) this fold and gradually widening in more posterior part of metanotum (Fig. 4). Legs rather short and slender, with open tympanum only on inner surface of fore tibia (Fig. 3), and with armament of hind tibia usual for this sibtribe (i.e. spines and denticles of this tibia not reduced, not very large and not thickened). Male tegmina distinctly protruding beyond abdominal apex and apices of hind femora; dorsal field with developed but slightly reduced stridulatory apparatus in proximal half (this apparatus having transverse stridulatory vein, 3 slightly or barely arcuate oblique veins, rather small and irregular mirror, and 3 almost S-shaped chords) and with simple and slightly oblique branches in distal half (Figs 14 15); lateral field with narrow areas between Sc and M, with $M$ and $\mathrm{R}$ fused with each other before middle of tegmen, and with rather numerous and somewhat oblique branches of Sc (Fig. 15). Female tegmina similar to those of male, but dorsal field with simple and slightly oblique longitudinal veins only, and lateral field without fusion of $\mathrm{M}$ and $\mathrm{R}$. Hind wings normally developed, longer than tegmina. Abdominal glands absent. Male anal plate rather short, with large and more or less flat median area, and with a pair of low transverse ridges before apex of this plate (Fig. 34); male genital plate distinctly longer than anal plate, with distal part separated from its more proximal part by transverse fold and gradually narrowing to narrowly rounded (almost acute) apex; in female, these plates more simple in shape, similar to those of other females of this subtribe. Male genitalia: epiphallus longer than half of genital length, somewhat laterally compressed, with a pair of high and almost lamellar posteromedial processes directed upwards and located very near each other, with a pair of short and almost rectangular posterolateral projections, and with slightly asymmetrical anterior part (Figs 20, 22, 30); ectoparameres elongate, rather thin but with distinctly thinner and arcuate proximal parts (Figs 21, 31,33); endoparameres also thin but shorter than ectoparameres, articulated with proximal parts of latters (Figs 21,31); rachis semimembranous and narrow but rather high, with acute apical hook and rounded subapical concavity (this concavity small, visible only in profile, located above apical hook; Figs 21-22, 31-32); formula consisting of a pair of vertical semisclerotized plates situated near each other and partly fused in ventral part (Figs 21-22, 31). Spermatophore with normal (large and round) ampulla, loop-like tubular anchor (attachment plate), and thin and long tube (Fig. 23); these parts of spermatophore formed in special cavities of genitalia schematically shown in Fig. 32 (ampulla, in cavity before ventral fold; loop-like anchor, in mould around this fold and in cavity above this fold between semisclerotized plates of formula; tube, in mould between previous cavity and apex of rachis). Ovipositor normally developed, with drilling apical part having numerous small tubercles (Fig. 36).

INCLUDED SPECIES. Type species only.

COMPARISON. The new genus is clearly distinguished from all the other genera of this subtribe by the lateral ocelli very large and contacting with each other, the median ocellus much smaller than lateral ones and located before them, and the male genitalia characteristic. These genitalia are somewhat similar to those of Eupodoscirtus Gorochov, 2004 and Fryerius in the epiphallus high (laterally compressed) and with rather short posterolateral projections, but these projections are much smaller in Eupodoscirtus and less distinct (almost undeveloped) in Fryerius, and the rachis is without any distinct apical hook in the both latter genera; from the other genera of Podoscirtina, the new genus differs in the following combination of genital characters: the epiphallus is higher, with the posteromedial processes distinctly longer or with the posterolateral projections clearly shorter and higher (wider); the rachis is not very large and not twisted in its distal part; the spermatophore is with the anchor rather long and distinctly loop-like (not short and simple), and with the tube much thinner and longer (for comparison see Figs 23 and 25, 28).

ETYMOLOGY. This generic name originates from the Latin morphological term "ocellus" and the generic name Malgasotrella (due to very large lateral ocelli).

\section{Ocellotrella sharovae Gorochov, sp.n.}

Figs $1-5,14-15,20-23,30-36$.

MATERIAL EXAMINED. Holotype - $\sigma^{7}$, Madagascar, Toamasina Prov., Moramanga Distr., Analamazaotra Forest Station near Andasibe Vill. (18 $\left.56^{\prime} \mathrm{S}, 48^{\circ} 25^{\prime} \mathrm{E}\right), \sim 900 \mathrm{~m}$, at light, 1-7.III.2013, A. Gorochov, L. Anisyutkin (ZIN). Paratypes: $80^{7}, 6 \circ$, same data as for holotype, but 11.II-20.III.2013 (ZIN); $2 \bigcirc^{7}, 1$, same province and district, $\sim 10 \mathrm{~km} \mathrm{NW}$ of Andasibe Vill., Torotorofotsy Forest Reserve, $\sim 1000 \mathrm{~m}$, at light, 22.II-11.III.2013, A. Gorochov (ZIN).

DESCRIPTION. Male (holotype). Body coloration: head light brown with yellowish lower half, greyish eyes, white lateral ocelli, brown transverse stripe between eyes along posterior edges of lateral ocelli, and numerous small yellowish to whitish rings on each antennal flagellum (Figs 1-2); pronotum light brown with poorly distinct darker (more or less brown) pattern on disc and numerous brown dots on lateral lobes (Figs 2, 5); meso- and metanotum as well as pleurites yellowish to whitish but with light brownish areas on lower parts of mesothoracic pleurites; legs yellowish with numerous light brown to brown dots and small spots (Figs 2, 5, 15); tegminal dorsal field almost uniformly greyish brown (somewhat lighter than brown transverse stripe on head) but with long and narrow whitish humeral stripe, shorter brown stripe between previous stripe and basal area, and small whitish spots at bases of MP+CuA1 branches in apical area (Figs 14-15); tegminal lateral field yellowish to whitish with greyish apical part, brown stripe along $\mathrm{M}$ running from base to middle of tegmen, and light brown vention (Fig. 15); abdomen light greyish brown with yellowish sternites and genital plate (except for distal part of this plate), and with light brown anal plate having almost brown subapical dorsal ridges. Structure of body parts as in generic diagnosis (Figs 1-2, 4-5, 34-35), but some of these parts with following possible species characters: inner tympanum moderately small, oval (Fig. 3); tegmina with stridulatory vein rather short and having rounded lateral part, with well developed plectrum, with angular shape mirror having distal half more or less cellular, with apical area of dorsal field having 7-8 longitudinal veins, with Sc having 10 11 branches rather long and arcuate in proximal half of lateral field but shorter and more straight (barely S-shaped) in distal half of this field, and with cross venation in both fields developed but moderately sparse (Figs 14-15); genitalia (Figs 20$22,30-33$ ) with epiphallus having narrow posteromedial processes as well as acute dorsal and rounded ventral corners of posterolateral projections (Fig. 22), and with ectoparameres having thin and elongate apical hook as well as small subapical tubercle on ventral edge (Fig. 33). Spermatophore as in Fig. 23.

Variations. Some male paratypes without or almost without traces of darker pattern and dots on pronotum and/or legs; their tegminal venation slightly varied (especially shape of mirror and number of cells in its cellular part); distal part of genital plate sometimes yellowish.

Female. General appearance as in males, but dorsal tegminal field with only $8-9$ slightly oblique longitudinal veins and 

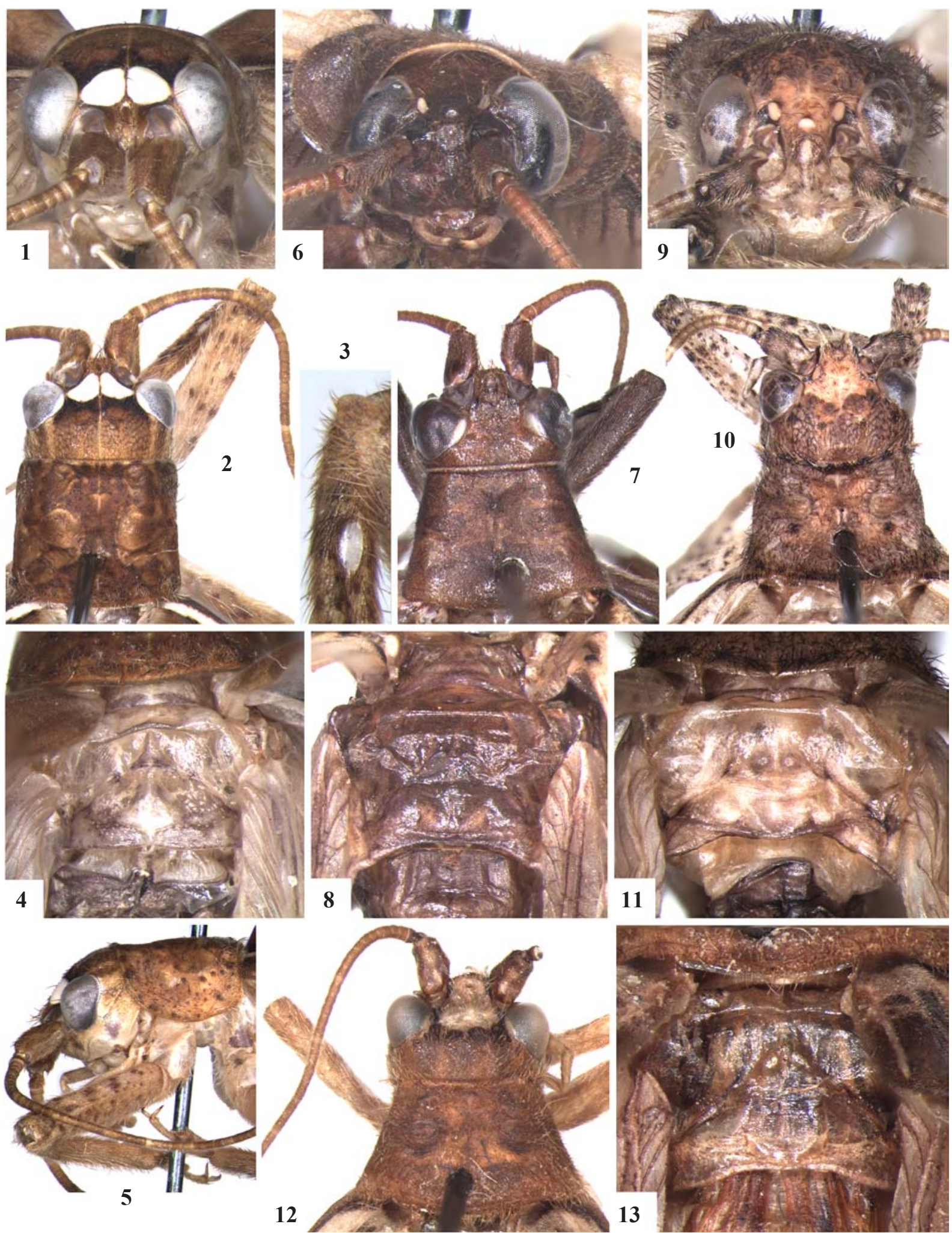

Figs 1-13. Ocellotrella gen.n. and Neozvenella Gor., males: $1-5-$ O. sharovae sp.n.; 6-8 - N. brunnea sp.n.; 9-11 - N. adunca sp.n.; 12-13 - N. paraucta sp.n.; 1, 6, 9 - head; 2, 5, 7, 10, 12 - head with pronotum and fore leg; 3 - proximal part of fore tibia with inner tympanum; 4, 8, 11, 13 - metanotal gland; 1, 6, 9 - frontal view; 2, 4, 7-8, 10-13 - dorsal view; 5 - lateral view.

Рис. 1-13. Ocellotrella gen.n. и Neozvenella Gor., самцы: 1-5 - O. sharovae sp.n.; 6-8 - N. brunnea sp.n.; 9-11 - N. adunca sp.n.; 1213 - N. paraucta sp.n.; 1, 6, 9 - голова; 2, 5, 7, 10, 12 - голова с переднеспинкой и передней ногой; 3 - проксимальная часть передней голени с внутренним тимпанумом; 4, 8, 11, 13 - метанотальная железа; 1, 6, 9 - спереди; 2, 4, 7-8, 10-13 - сверху; 5 - сбоку. 
rather numerous crossveins, lateral tegminal field with 8-9 branches of Sc and moderately sparse crossveins, as well as anal plate insignificantly smaller than in male. Genital plate also short (but not small), gradually narrowing to apex, with distinct but rounded and not deep posteromedian notch, and with a pair of short rounded lobes around this notch; apical part of ovipositor as in Fig. 36.

Length in mm. Body: $\sigma^{7} 15-15.5$, $912-14$; body with wings: $\sigma^{7} 16-18.5$, o 15-17; pronotum: $\sigma^{\top} 2.3-2.5$, + 2.4 2.5; tegmina: $\sigma^{7} 11.5-13$, o 10-11; hind femora: $\sigma^{7} 9-10$, 우 9.5-10; ovipositor 8.2-8.8.

COMPARISON. The new species differs from the other related taxa by the characters given in the generic diagnosis.

ETYMOLOGY. This species is named in memory of the well-known entomologist and ecologist I.Kh. Sharova for her big contribution in the study of Coleoptera life forms very useful for my work on Ensifera life forms.

\section{Genus Neozvenella Gorochov, 2004 \\ Neozvenella brunnea Gorochov, sp.n. \\ Figs 6-8, 16, 24-25, 37-42.}

MATERIAL EXAMINED. Holotype - $0^{7}$, Madagascar, Toamasina Prov., Moramanga Distr., Analamazaotra Forest Station near Andasibe Vill. $\left(18^{\circ} 56^{\prime} \mathrm{S}, 48^{\circ} 25^{\prime} \mathrm{E}\right), \sim 900 \mathrm{~m}$, at light, 11 28.II.2013, A. Gorochov, L. Anisyutkin (ZIN). Paratypes: $20^{2}$, same data as for holotype, but 8-20.III.2013, A. Gorochov (ZIN).

DESCRIPTION. Male (holotype). Body rather small for this genus. Coloration: head, thorax, legs and abdomen brown with greyish ocelli, almost dark brown very small stripes along medial edges of lateral ocelli, light brown to yellowish antennae (except for scapes) and mouthparts, light brown all sternites and genital plate, intermediate between brown and light brown pterothoracic dorsum and pleurites as well as hind femora and cerci, and a pair of yellowish spots on anal plate (Figs 6-8, 41); tegmina transparent with greyish tinge, small dark brown spot near plectrum, brown diagonal vein in stridulatory apparatus as well as 2 medial chords and distal half of area between these chords, a few small light brown spots along distal edge of mirror and venation of distal half of dorsal field (but some of these veins darker, almost brown), yellow most part of M, greyish brown $\mathrm{R}$ and stock of $\mathrm{Sc}$, and brownish yellow branches of Sc (Fig. 16). External structure of body typical of Neozvenella, but scape almost 2.2 times as wide as rostrum between antennal cavities, lateral ocelli rather small and oval as well as slightly larger than round median ocellus (Figs 6-7), metanotal gland non-pubescent as well as with large and moderately deep central concavity having a pair of small and obliquely transverse tubercles at centre (Fig. 8), both tympana open and oval (inner tympanum rather large, almost 1.5 times as long as outer tympanum and slightly wider than latter one), tegmina approximately reaching middle of hind tibiae and with venation as in Fig. 16, hind wings distinctly protruding beyond tegminal apices, anal plate with large but barely distinct semimembranous area and with distal part somewhat similar to that of Ocellotrella gen. n. (Fig. 41), and genital plate with distal part gradually narrowing to narrowly rounded apex but longitudinally folded and looking as very narrow from below (Fig. 42). Genitalia (Figs 24, 37-40) similar to those of $N$. picta Gorochov, 2004, but posteromedian epiphallic process with clearly less projected posteromedial lobules around very narrow (but not very deep) posteromedian notch and with posterolateral lobules hooked and reaching almost apices of previous lobules (in N. picta, latter lobules almost not hooked and distinctly not reaching apices of posteromedial lobules), each posterolateral epiphallic projection distinctly wider in distal half and with much narrower notch between this projection and its apical hook, and rachis distinctly less arcuate in profile and very narrowly rounded but not clearly acute at apex (in dorsal view) as well as with very small subapical dorsal tubercle (in lateral view; Fig. 39); spermatophore as in Fig. 25.

Variations. Male paratype with lateral ocelli whitish, pronotal disc having barely lighter areas, area between $\mathrm{R}$ and $\mathrm{M}$ in tegmina brownish grey, cerci light greyish brown, and each posterolateral epiphallic projection of genitalia near apex of its apical hook having distinct angular denticle.

Female unknown

Length in mm. Body $10-11$; body with wings $18-19$; pronotum 1.8-2; tegmina 13-14; hind femora 8-8.5.

COMPARISON. The new species is most similar and related to $N$. picta, but it differs from the latter species in almost uniformly brown coloration of head and pronotum, darker legs and abdomen, and the male genital characters listed above (in the description of this species). From all the other congeners, the new species is distinguished by the same characters as $N$. picta (except for coloration).

ETYMOLOGY. This species name is the Latin word "brunnea" (brown) due to the color of the body.

\section{Neozvenella picta Gorochov, 2004}

MATERIAL EXAMINED. Madagascar: 20 ", "Tamatave [= Toamasina?] Prov., Mantadia - Andasibe", Analamazaotra National Park, Special Reserve (18 $\left.93^{\prime} \mathrm{S}, 48^{\circ} 43^{\prime} \mathrm{E}\right)$, at light, 10.XII.2004, G. Beccaloni (NHM, ZIN); $6 \mathrm{O}^{7}, 3$, , Toamasina Prov., Moramanga Distr., Analamazaotra Forest Station near Andasibe Vill. (18 $56^{\circ} \mathrm{S}$, $48^{\circ} 25^{\prime} \mathrm{E}$ ), $\sim 900 \mathrm{~m}$, at light, 1-20.III.2013, A. Gorochov (ZIN); $1 \mathrm{O}^{\prime}$, same province and district, $\sim 10 \mathrm{~km} N W$ of Andasibe Vill., Torotorofotsy Forest Reserve, $\sim 1000 \mathrm{~m}$, at light, 22.II-11.III.2013, A. Gorochov (ZIN).

DESCRIPTION. Female (nov.). General appearance similar to that of male holotype [Gorochov, 2004] but with following characteristic features: coloration yellowish with brown head dorsum and apices of mandibles, dark brown eyes, light brown apices of both labrum and maxillae, a pair of blackish or dark brown dots on middle part of pronotal disc (dark or darkish stripe along posterior edge of this disc, developed in all males, absent), light brown tegminal dorsal field having barely darker venation, semitransparent and yellowish tegminal lateral field having light brown veins, and sometimes light brown tibiae and areas on tarsi; external structure of body similar also to that of male of $N$. brunnea sp.n., but dorsal tegminal field with only $8-10$ slightly irregular oblique branches as well as moderately numerous and partly irregular crossveins, and lateral tegminal field with 89 obliguely longitudinal branches of Sc and without crossveins; genital plate barely narrowing to distinctly notched apex having a pair of widely rounded apical lobes around angular but not deep posteromedian notch; ovipositor more or less similar to that of Ocellotrella gen.n.

Length in $\mathrm{mm}(+)$. Body 12.5-13.5; body with wings 18 19; pronotum 1.8-1.9; tegmina $13.2-13.7$; hind femora $7-$ 7.5 ; ovipositor $5.5-5.8$.

REMARKS. All the above-listed males are practically identical to each other and to the holotype of N. picta in their characteristic coloration, size and structure of body; but one of them lacks dark dots on the pronotal disc, and there is a slight variability in the shape of the posterolateral epiphallic projections. The species is recorded from this locality at the first time, because it was described from another Madagascan locality [Gorochov, 2004: "Ambohitomba"]). 

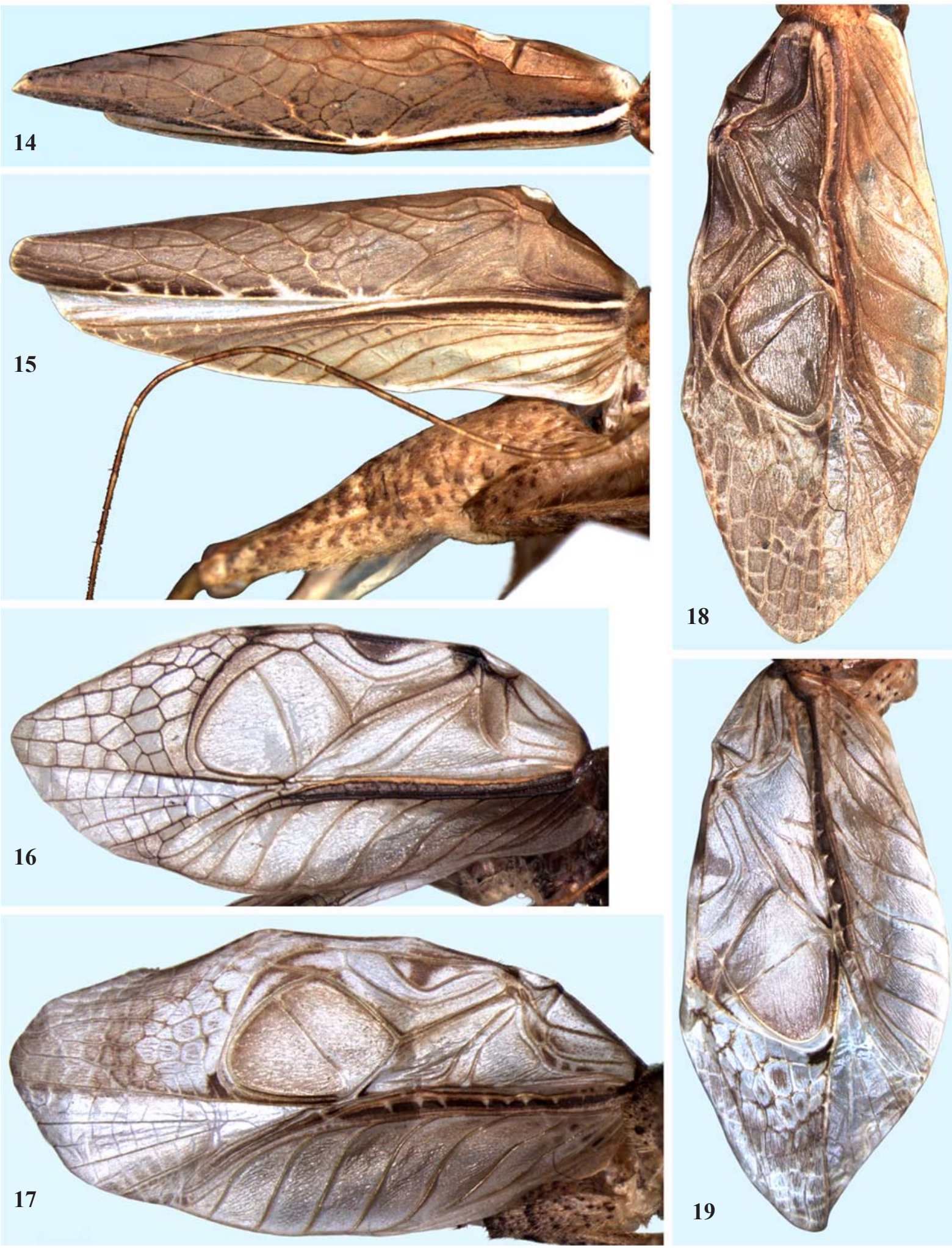

Figs 14-19. Ocellotrella gen.n. and Neozvenella Gor., males: 14-15 - O. sharovae sp.n.; $16-N$. brunnea sp.n.; $17-N$. adunca sp.n.; 18 - N. paraucta sp.n.; $19-N$. aucta Gor.; 14 - right tegmen in resting position; 15 - right tegmen in partly spreading position and right hind femur; 16-19 - right tegmen in completely spreading position; 14 - dorsal view; 15 - lateral view.

Pис. 14-19. Ocellotrella gen.n. и Neozvenella Gor., самцы: 14-15 - O. sharovae sp.n.; 16 - N. brunnea sp.n.; 17 - N. adunca sp.n.; 18 - N. paraucta sp.n.; 19 - N. aucta Gor.; 14 - правое надкрылье в состоянии покоя; 15 - правое надкрылье в частично расправленном состоянии и правое заднее бедро;16-19 - правое надкрылье в полностью расправленном состоянии; 14 - сверху; 15 - сбоку 
Neozvenella adunca Gorochov, sp.n. Figs 9-11, 17, 26, 43-46.

MATERIAL EXAMINED. Holotype - $\sigma^{7}$, Madagascar, Toamasina Prov., Moramanga Distr., Analamazaotra Forest Station near Andasibe Vill. $\left(18^{\circ} 56^{\prime} \mathrm{S}, 48^{\circ} 25^{\prime} \mathrm{E}\right), \sim 900 \mathrm{~m}$, at light, 8 20.III.2013, A. Gorochov (ZIN). Paratypes: $2 O^{\top}$, same province and district, $\sim 10 \mathrm{~km} \mathrm{NW}$ of Andasibe Vill., Torotorofotsy Forest Reserve, $\sim 1000 \mathrm{~m}$, at light, 22.II-11.III.2013, A. Gorochov (ZIN).

DESCRIPTION. Male (holotype). Body medium-sized for this genus. Head and pronotum light brown with following pattern: ocelli and area between them yellowish (this area continuing also behind ocelli but not reaching posterior edges of eyes); posterodorsal part of head and pronotal disc with sparse greyish brown dots; lower half of head and small median spot at apex of rostrum as well as lateral lobes of pronotum yellowish to almost whitish, but maxillary palpi with greyish areas and small browhish grey spots, and lower parts of epicranium and lateral lobes of pronotum with rather dense dark brown dots; antennae with blackish large ring on apex of scape and small ring in region of pedicel, and with greyish antennal flagellum having numerous small whitish spots; pronotal disc also with very dark dense and large dots along its anterior and posterior edges (Figs 9-10). Pterothoracic dorsum (Fig. 11) and pleurites as well as thoracic sternites and legs yellowish to whitish, but legs with numerous dark dots and small spots partly fused with each other on dorsal and distal parts of hind femur as well as completely fused on ventral and lateral surfaces of hind tibia (dorsal surface of this tibia with 3 large greyish areas); tegmina transparent with light brown to yellowish venation (except for almost whitish $\mathrm{M}$ ), brown area between $\mathrm{R}$ and $\mathrm{M}$ interrupted by several whitish spots in regions of crossveins, and a few small light brown to greyish brown marks on dorsal field (Fig. 17); abdomen brown to light brown with whitish sternites and genital plate (anterior abdominal sternites with light greyish brown areas, posterior ones with brownish grey dots, and genital plate with a pair of small darkish marks in proximal half) as well as posterolateral parts of two last tergites and distal half of anal plate (apical part of this plate somewhat darkened), and with contrastingly spotted cerci. External structure of body similar to that of $N$. aucta Gorochov, 2004; however, scape approximately 1.2 times as wide as rostrum between antennal cavities, ocelli almost as in $N$. brunnea sp.n., metanotal gland also as in this species but with central tubercles more rounded (Fig. 11), both tympana almost equal to each other in size and similar to outer tympanum of $N$. brunnea sp.n. in size and shape, tegmen as in this species in length and with venation as in Fig. 17, anal plate also almost as in this species, and genital plate with distal part more or less similar to that of Ocellotrella gen. n. Genitalia (Figs 26, 43-46) also similar to those of $N$. aucta, but posteromedian epiphallic process with distinctly wider apex having clearly wider and rounded median notch, base of this process with a pair of rather large lateral tubercles directed backwards (Fig. 45), posterolateral epiphallic projections moderately narrow and strongly arcuate (hook-like) as well as with very small denticle on each posterior edge (Fig. 45), ectoparameres longer as well as with thin and acute apical hook directed more backwards than downwards (Fig. 46), rachis with thinner and longer apical hook as well as with less widened subapical part (Figs 26, 43-44).

Female unknown.

Length in mm. Body 11.5-12.5; body with wings 20-21; pronotum 2.2-2.4; tegmina 14-15; hind femora 8.5-9.5

COMPARISON. The new species is most similar and related to $N$. aucta but distinguished from the latter species by the absence of any large or moderately large dark marks on the both head dorsum and pronotal disc, and the above-listed characters of the male genitalia (for comparison see Figs 4346 and 51-55). From all the other congeners, the new species differs in the same characters of body structure as N. aucta.

ETYMOLOGY. This species name is the Latin word "adunca" (hooked) due to the shape of the posterolateral epiphallic projections.

\section{Neozvenella aucta Gorochov, 2004}

Figs 19, 51-55.

MATERIAL EXAMINED. Madagascar: $13 \sigma^{7}, 1$, Toamasina Prov., Moramanga Distr., Analamazaotra Forest Station near Andasibe Vill. (18 $\left.56^{\prime} \mathrm{S}, 48^{\circ} 25^{\prime} \mathrm{E}\right), \sim 900 \mathrm{~m}$, at light, 1-20.III.2013, A. Gorochov, L. Anisyutkin (ZIN); $10^{\top}$, same province and district, $\sim 10 \mathrm{~km}$ NW of Andasibe Vill., Torotorofotsy Forest Reserve, $\sim 1000$ $\mathrm{m}$, at light, 22.II-11.III.2013, A. Gorochov (ZIN).

DESCRIPTION. Female (nov.). General appearance similar to that of male holotype [Gorochov, 2004] but with following characteristic features: coloration yellowish with a pair of light brown longitudinal bands on posterior half of head dorsum, brown edges of antennal cavities, brown to light brown marks on scape, numerous small light brown spots on antennal flagellum, brown median band on pronotal disc and a pair of large dots around this band, very sparse darkish dots on upper half of head and on lateral tegminal fields, numerous dark and darkish dots on lateral pronotal lobes and on legs (some of threse dots large and sometimes looking as small dark spots on fore and middle tibiae), row of frequent small light brown spots between $\mathrm{R}$ and $\mathrm{M}$ in each tegmen, and similar but sparser and irregularly situated spots and dots on dorsal tegminal field; external structure of body similar also to that of male of $N$. adunca sp.n. but distinguished by somewhat smaller inner tympanum, dense and almost completely cellular venation of dorsal tegminal field (in this venation, traces of 6-7 obliquely transverse branches poorly visible only), lateral tegminal field with normal longitudinal veins (including 11-12 oblique branches of Sc) and more or less cellular crossvenation between them; genital plate trapezoidal with widely rounded posterolateral corners and barely concave posterior edge; ovipositor more or less similar to that of Ocellotrella gen. n.

Length in $\mathrm{mm}(+)$. Body 12 ; body with wings 22 ; pronotum 2.2; tegmina 15.5; hind femora 10; ovipositor 8 .

REMARKS. The males examined are similar to each other and to the holotype of $N$. aucta in general appearance and structure of the male genitalia (this species was described also from "Analamazaotra" [Gorochov, 2004]). However, they are somewhat variable in coloration and shape of some male genital structures, but a dark pattern on the head and pronotum as well as numerous darkened dots on these structures and on legs are developed practically always.

\section{Neozvenella paraucta Gorochov, sp.n.}

Figs 12-13, 18, 27-29, 47-50.

MATERIAL EXAMINED. Holotype - $\sigma^{7}$, Madagascar, Toamasina Prov., Moramanga Distr., $\sim 10 \mathrm{~km}$ NW of Andasibe Vill. $\left(18^{\circ} 56^{\prime} \mathrm{S}, 48^{\circ} 25^{\prime} \mathrm{E}\right)$, Torotorofotsy Forest Reserve, $\sim 1000 \mathrm{~m}$, at light, 22.II-11.III.2013, A. Gorochov (ZIN).

DESCRIPTION. Male (holotype). Body medium-sized for this genus. Coloration: head brown with large yellowish area on dorsum between rostral apex and posterior parts of eyes (this area including all ocelli, but they almost light brown), yellowish to light brown lower part of epicranium and mouthparts, almost dark brown scape having light brown small dorsal marks, blackish pedicel, and brown to light brown antennal flagellum; pronotum brown with poorly dis- 

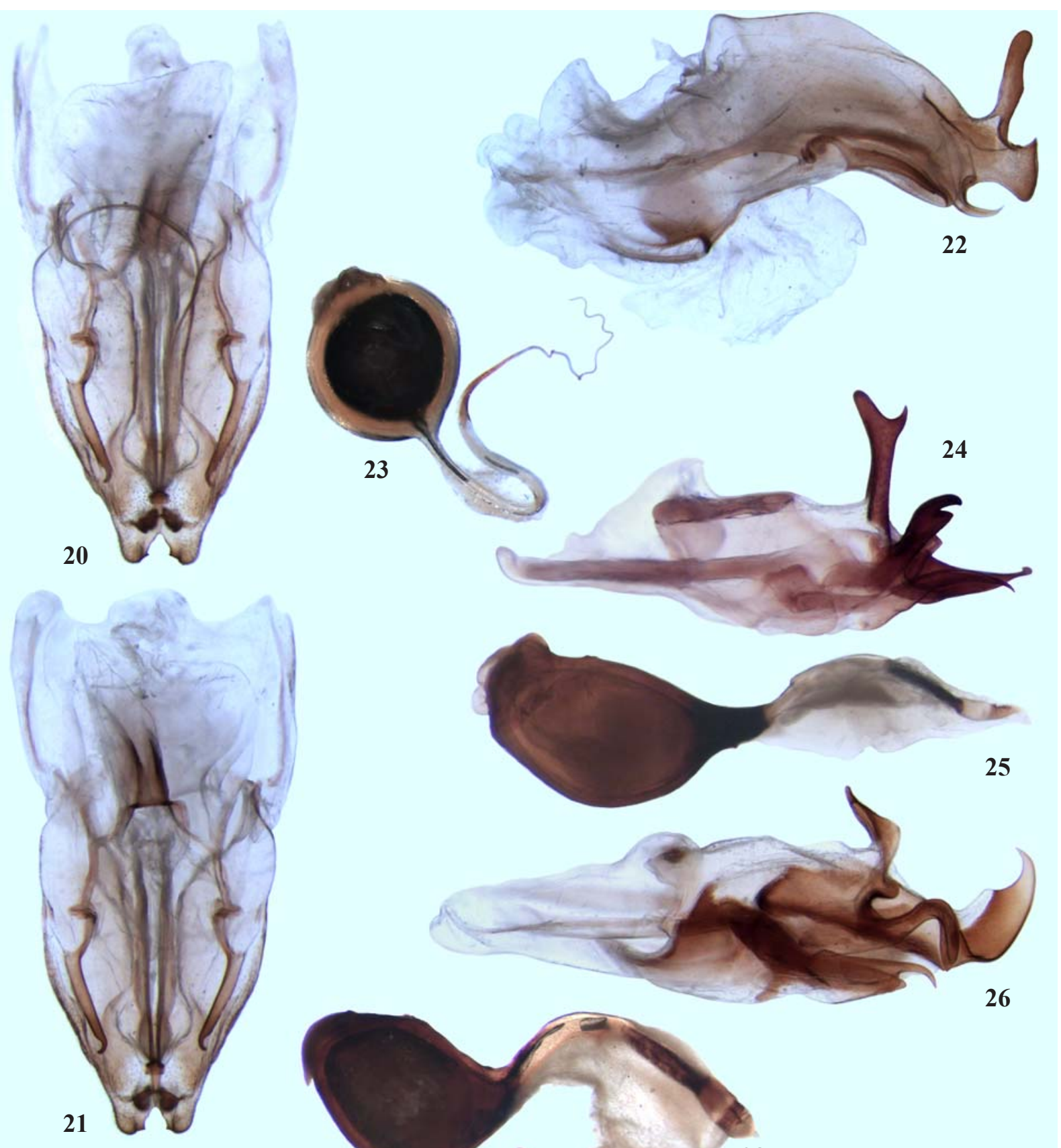

22

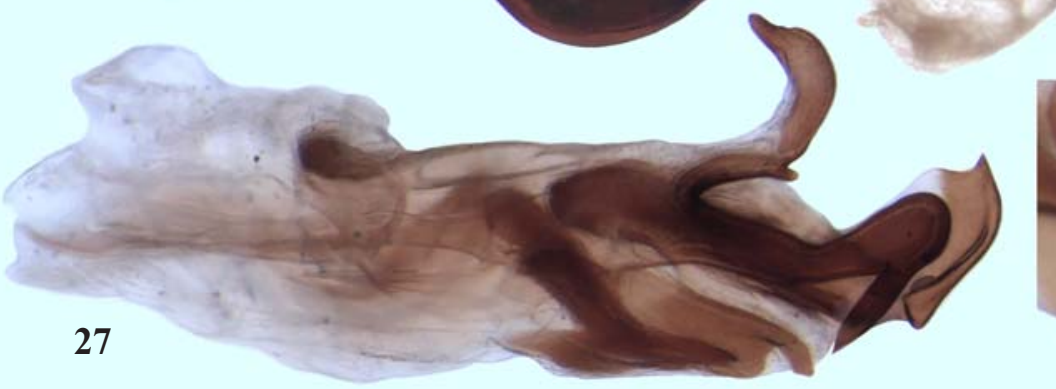

\section{8}

Figs 20-29. Ocellotrella gen.n. and Neozvenella Gor., male: 20-23 - O. sharovae sp.n.; 24-25 - N. brunnea sp.n.; 26 - N. adunca sp.n.; 27-29-N. paraucta sp.n.; 20-22, 24, 26-27 - genitalia; 23, 25, 28 - spermatophore; 29 - left posterolateral projection of epiphallus and distal part of ectoparamere; 20 - dorsal view; 21 - ventral view; 22-28 - lateral view; 29 - lateral and slightly dorsal view.

Pис. 20-29. Ocellotrella gen.n. и Neozvenella Gor., самец: 20-23 - O. sharovae sp.n.; 24-25 - N. brunnea sp.n.; 26 - N. adunca sp.n.; 27-29 - N. paraucta sp.n.; 20-22, 24, 26-27 - гениталии; 23, 25, 28 - сперматофор; 29 - левый заднебоковой выступ эпифаллуса и дистальная часть эктопарамера; 20 - сверху; 21 - снизу; 22-28 - сбоку; 29 - сбоку и слегка сверху. 

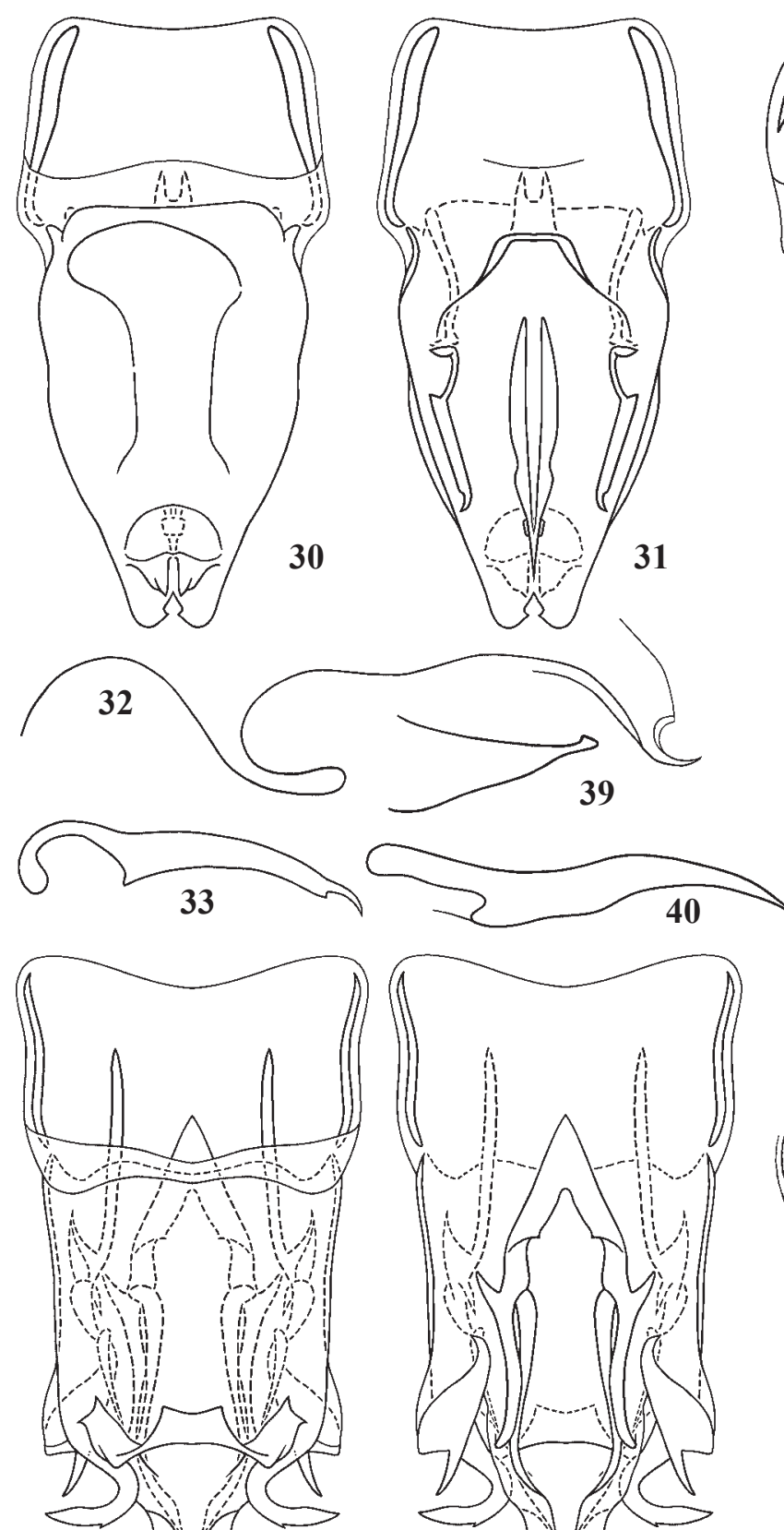

43

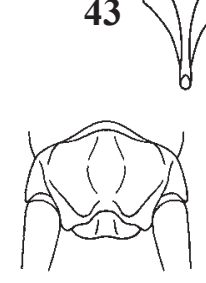

34

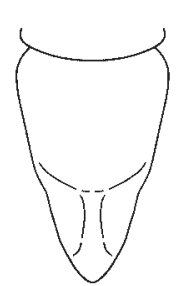

35

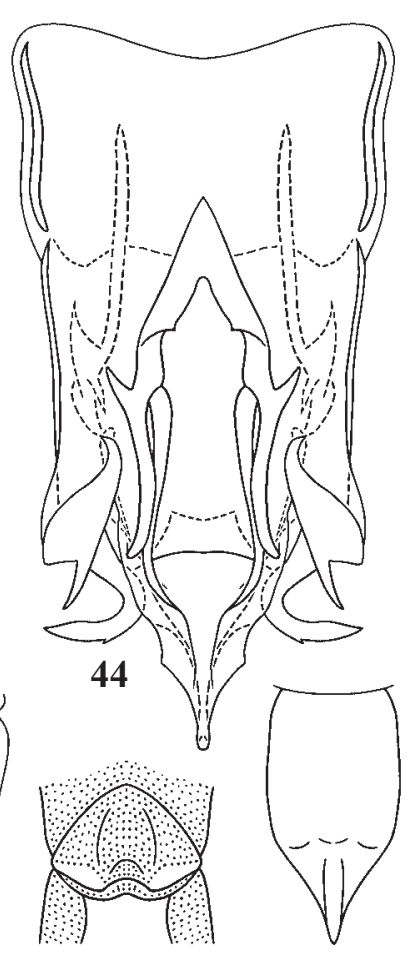

41
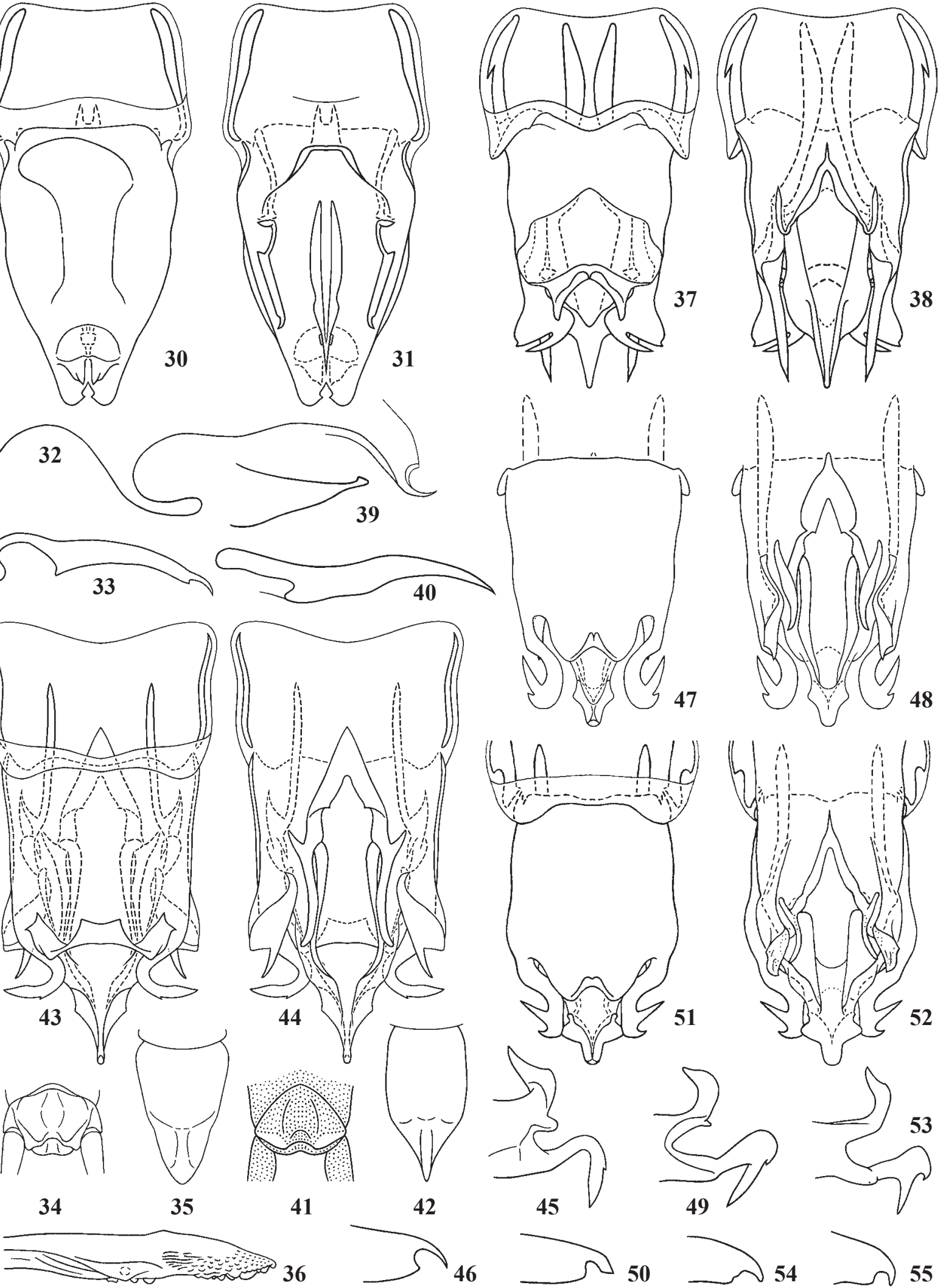

Figs 30-55. Ocellotrella gen.nov. and Neozvenella Gor. 30-36 - O sharovae sp.nov.; 37-42 - N. brunnea sp.nov.; 43-46 - N. adunca sp.nov.; 47-50 - N. paraucta sp.nov.; 51-55 - N. aucta Gor.; 30-31, 37-38, 43-44, 47-48, 51-52 - male genitalia with or without foreparts; 32 - rachis and scheme of sagittal section of more proximal part of male genitalia; 33, 40, 46, 50, 54-55 — left ectoparamere or its distal part; 34, 41 - male anal plate; 35, 42 - male genital plate; 36 - apical part of ovipositor; 39 - distal part of rachis; 45, 49, 53 - distal half of epiphallus; $30,34,37,41,43,47,51$ - dorsal view; $31,35,38,42,44,48,52$ - ventral view; 32-33, 36, 39-40, 45-46, 49-50, 53-55- lateral view. 
tinct light brown marks on disc (Fig. 12) and slight traces of darkish dots on lower half of each lateral lobe; pterothoracic dorsum light brown (Fig. 13); pleurites and legs light brown to yellowish (femora in general barely or slightly darker than other parts of legs), with almost brown both distal part of hind femur and hind basitarsus; tegminal dorsal field light brown, semitransparent, with basal area and region of chords as well as some spots near plectrum and around mirror almost brown (but base of this basal area with distinct yellowish spot); tegminal lateral field similar to dorsal one in color but with yellowish humeral stripe and brown most part of R-M area (this area with a few small yellowish spots in distal half; Fig. 18); abdominal tergites and anal plate brown to light brown; all sternites and genital plate more or less yellowish; cerci light brown. External structure of body very similar to that of N. adunca sp.n. (Figs 12-13, 18); genitalia (Figs 27, $29,47-50$ ) most similar to those of $N$. aucta but distinguished by posteromedian epiphallic process with a pair of small (but distinct) lateral tubercles at base (these tubercles directed backwards and somewhat smaller than in N. adunca sp.n.; compare Figs 45 and 49), each posterolateral epiphallic projection with longer and more oblique ventral spine as well as smaller and less distinct (located very near previous spine) ventroapical denticle (compare Figs 49 and 53), ectoparamere with apical hook more similar to that of $N$. adunca sp.n. (i.e. longer and less strongly curved downwards than in $N$. aucta) but less acute at apex (compare Figs 46, 50, 54-55), and rachis with clearly narrower subapical part (see Figs 47 48 and 51-52); spermatophore as in Fig. 28.

Female unknown.

Length in $\mathrm{mm}$. Body 14; body with wings 21.5 ; pronotum 2.3; tegmina 16 ; hind femora 10.5 .

COMPARISON. The new species is most similar and related to $N$. aucta; it differs from the latter species in different body coloration (without both dark pattern on pronotal disc and dark or darkish dots on legs) and some small characters of the male genitalia listed in the descrip- tion. From N. adunca sp.n. and all the other congeners, the new species is distinguished by the same genital characters as $N$. aucta.

ETYMOLOGY. The name of this species originates from the name of its most similar and related species ( $N$. aucta) with the addition of the Latinized Greek prefix "para-" (near).

\section{Neozvenella bona Gorochov, 2004}

MATERIAL EXAMINED. Madagascar: $170^{7}$, Toamasina Prov., Moramanga Distr., Analamazaotra Forest Station near Andasibe Vill. (18 $\left.56^{\prime} \mathrm{S}, 48^{\circ} 25^{\prime} \mathrm{E}\right), \sim 900 \mathrm{~m}$, at light, 11.II-20.III.2013, A. Gorochov, L. Anisyutkin (ZIN)

REMARKS. The above-listed males are almost identical to each other and to the holotype of $N$. bona described also from "Analamazaotra". They are similar to N. picta in their general appearance (including yellowish coloration with dark head dorsum and small marks on strudulatory apparatus) but without any dark marks on the pronotum and with some distinct differences in the male genitalia [Gorochov, 2004].

Acknowledgements. I thank all the colleagues who helped me with the field work and provided some specimens for my study. This study was performed in the frames of the state research project No. AAAA-A19-119020690101-6 (Russian Federation).

\section{References}

Gorochov A.V. 2004. Taxonomy of Podoscirtinae (Orthoptera: Gryllidae). Part 3: Podoscirtini from Madagascar and nearest regions // Zoosystematica rossica. Vol.12. No.2 (2003). P.187-215.

Gorochov A.V. 2006. Taxonomy of Podoscirtinae (Orthoptera: Gryllidae). Part 5: new Indo-Malayan and Madagascan Podoscirtini // Zoosystematica rossica. Vol.15. No.1. P.33-46.

Gorochov A.V. 2021. Taxonomy of Podoscirtinae (Orthoptera: Gryllidae). Part 13: new taxa of the subtribe Podoscirtina from Africa // Zoosystematica rossica. Vol.30. No.1. P.64-77.

Pис. 30-55. Ocellotrella gen.n. и Neozvenella Gor.: 30-36-O. sharovae sp.n.; 37-42 - N. brunnea sp.n.; 43-46 — N. adunca sp.n.; 47-50 - N. paraucta sp.n.; 51-55 - N. aucta Gor.; 30-31, 37-38, 43-44, 47-48, 51-52 - гениталии самца с передними частями или без них; 32 - рахис и схема сагиттального сечения более проксимальной части гениталий самца; $33,40,46,50,54-55$ - левый эктопарамер или его дистальная часть; 34, 41 - анальная пластинка самца; 35,42 - генитальная пластинка самца; 36 вершинная часть яйцеклада; 39 - дистальная часть рахиса; $45,49,53$ - дистальная половина эпифаллуса; $30,34,37,41,43,47$, 51 - сверху; $31,35,38,42,44,48,52$ - снизу $32-33,36,39-40,45-46,49-50,53-55$ - сбоку. 